\title{
Perception Disturbance
}

National Cancer Institute

\section{Source}

National Cancer Institute. Perception Disturbance. NCI Thesaurus. Code C35274.

A misperception of sensory stimuli. 